\title{
DETERMINATION OF PROTOPINE IN FUMARIA DENSIFLORA DC. BY TLC- DENSITOMETRIC AND SPECTROPHOTOMETRIC METHOD
}

\author{
FUMARIA DENSIFLORA DC.' DA OPTİK DANSITTOMETRİK VE \\ SPEKTROFOTOMETRIK YÖNTEMLE PROTOPIN MIKTAR TAYINI
}

\section{Tuğçe FAFAL， Mustafa Ali ÖNÜR}

Ege University, Faculty of Pharmacy, Department of Pharmacognosy, 35100

İzmir - TURKEY

\begin{abstract}
The isoquinoline alkaloid protopine in Fumaria densiflora DC. (Fumariaceae) was quantitatively determined by TLC-densitometry and spectrophotometry. In TLC-densitometry two different solvent systems as toluene : chloroform : methanol : \% 25 ammonium hydroxide (5:3:1:1) and cyclohexane : diethylamine (9:1) were used and protopine was detected as 0.351 and $0.352 \%$ respectively. The content of protopine in Fumaria densiflora DC. was estimated as $0.366 \%$ in spectrophotometric method. The quantitative data obtained by the use of two techniques were in good agreement.
\end{abstract}

Key Words: Fumaria densiflora DC., Fumariaceae, Protopine ÖZET

Fumaria densiflora DC.' daki (Fumariaceae) izokinolin alkaloitlerinden olan protopinin \% miktarl optik dansitometrik ve spektrofotometrik yöntemlerle saptanmıştır. Optik dansitometrik yöntemde toluen: kloroform: metanol : \%25 amonyum hidroksit (5:3:1:1) ve siklohekzan: dietilamin (9:1) olmak üzere iki farklı solvan sistemi uygulanmış olup protopin miktarl \% 0.351 ve \% 0.352 olarak bulunmuştur. Spektrofotometrik yöntemde ise Fumaria densiflora DC.' nın protopin miktarl \% 0.366 olarak saptanmıştır. Çalışmamı sonucunda bu iki yöntemde bulunan değerlerin birbiriyle uyumlu olduğu görülmüştür.

Anahtar Kelimeler: Fumaria densiflora DC., Fumariaceae, Protopin 


\section{INTRODUCTION}

Plants of the genus Fumaria have been used in traditional medicine as anti-hypertensives, diuretics, hepatoprotectants and laxatives (to treat gastrointestinal disorders), as well as in the treatment of some skin diseases (raches or conjunctivitis) $(1,2)$. The biological activity of Fumaria is mostly associated with the presence of isoquinoline alkaloids in the plant. In the last few years, a large number of scientific reports have been described the properties of Fumaria $(3,4)$. There are seventeen wild-growing species belonging to this genus $(5,6)$.

Protopine is the most usual alkaloid found in Fumaria whatever type it is the active family of compound of the plant (7). It is an isoquinoline alkaloid with multiple pharmacological actions, such as inhibition of calcium influx through both voltage and receptor-operated channels (8) and inhibition of rabbit blood platelet aggregation (9). It also posesses anti-cholinergic and antihistaminic (10) as well as anti-bacterial (11) activities. Structure of protopine is shown figure 1.

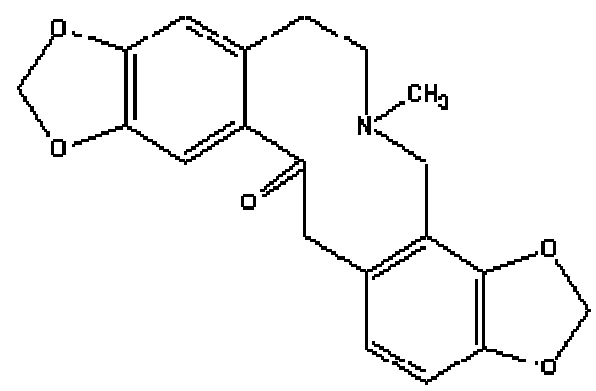

Figure 1. Protopine

The alkaloids isolated from the previous studies on Fumaria species are shown in table 1.

Table 1. The alkaloids isolated from Fumaria species

\begin{tabular}{|c|c|c|}
\hline \multicolumn{1}{|c|}{ SPECIES } & NAME OF ALKALOIDS & NUMBER OF \\
LITERATURE
\end{tabular}




\begin{tabular}{|c|c|c|}
\hline Fumaria gaillardotii Boiss. & $\begin{array}{c}\text { Protopine, fumaritine, fumaricine, l-stylopine, dl-bicuculline, N- } \\
\text { methylhydrastine }\end{array}$ & 15 \\
\hline Fumaria judaica Boiss. & $\begin{array}{l}\text { Protopine, } d \text {-adlumidine, } \beta \text {-allocyrtopine, l-stylopine, } \\
\text { fumaritine, coptisine, l-scoulerine }\end{array}$ & 16 \\
\hline $\begin{array}{l}\text { Fumaria macrocarpa } \\
\text { Parlatore }\end{array}$ & $\begin{array}{l}\text { Protopine, crytopine, fumariline, l-sinactine, } \alpha \text {-adlumine, } \\
\text { coptisine }\end{array}$ & 17 \\
\hline Fumaria cilicica Hausskn. & $\begin{array}{l}\text { Sanguinarine, protopine, cryptopine, d-corydaline, l-sinactine, dl- } \\
\text { bicuculline, l-scoulerine }\end{array}$ & 19 \\
\hline Fumaria densiflora DC. & $\begin{array}{l}\text { Fumaramine, protopine, cryptopine, coptisine, palmatine, } \\
\text { adlumidecine, sinactine, densiflorine, parfumine, parfumidine, } \\
\text { fumaritine, cheilanthifoline, }( \pm) \text {-scoularine, isosalutaridine, }( \pm)- \\
\text { aldumidine, N-methylhydrasteine, fumariline, }( \pm) \text {-bicuculline, } \beta \text { - } \\
\text { allocrptopine, fumaricine, fumaritridine, fumarophycine, } \\
\text { fumarofine, corytuberine, cis-N-methylstylopinium iodide, } \\
\text { stylopine, fumaflorine, N-metylstylopine, dihydrosanguinarine }\end{array}$ & $20,23,25,26,29$ \\
\hline Fumaria bella P.D. & $\begin{array}{l}\text { Isoboldine, sanguinarine, }(+) \text {-bicuculline, coptisine, protopine, } \\
(+) \text {-fumariline, }(+) \text {-parfumine, }(-) \text {-cheilanthifoline, }(-)- \\
\text { scoulerine, }(-) \text {-stylopine, }(+) \text {-adlumine, }(+) \text {-parfumine }\end{array}$ & 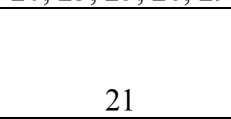 \\
\hline Fumaria asepala Boiss. & $\begin{array}{c}\text { Protopine, cryptopine, 1-stylopine, 1-scoulerine, d-bicuculline, } \\
\text { sanguinarine }\end{array}$ & 22 \\
\hline Fumaria parviflora Lam. & $\begin{array}{l}\text { Protopine, parfumine, d-bicuculline, hydrastine, N- } \\
\text { methlhydrastine, N-methylhydrasteine, microcarpine, } \\
\text { sanguinarine, adlumiceine, coptisine, fumaritine, sinactine, N- } \\
\text { methylstylopine }\end{array}$ & 24,27 \\
\hline $\begin{array}{l}\text { Fumaria petteri Reichb. } \\
\text { subsp. thuretii }\end{array}$ & $\begin{array}{l}\text { Protopine, fumariline, fumaritine, fumaricine, l-sinactine, 1- } \\
\text { scoulerine, coptisine, l-capnoidine }\end{array}$ & 24 \\
\hline Fumaria kralikii Jordan & $\begin{array}{l}\text { Protopine, cryptopine, parfumine, l-scoulerine, d-bicuculline, d- } \\
\text { adlumine, N-methylhydrasteine, sanguinarine }\end{array}$ & 24 \\
\hline Fumaria schramii Pugsley & $\begin{array}{l}\text { Fumaritine, corytuberine, parfumine, fumaricine, adlumidicein, } \\
\text { adlumicein, N-metylstylopine, coptisine, O- } \\
\text { metylfumaroficine, stylopine, fumaroficine, cryotopine, sinaktin, } \\
\text { protopine, fumariline, palmatine }\end{array}$ & 26 \\
\hline Fumaria agraria Lag. & $\begin{array}{l}\text { Adlumiceine, coptisine, cryptopine, fumariline, fumaritine, } \\
\text { fumarophycine, parfumine, } \\
\text { Domesticine, }(+) \text {-isoboldine, dihydrolstopine, } \\
\text { noroxyhydrastinine, oxyydrastinine, (-)-stylopine, protopine, (-)- } \\
\text { fumaritine-N-oxide, (+)-parfumine }\end{array}$ & 27,28 \\
\hline Fumaria muralis & $\begin{array}{l}\text { Coptisine, cryptopine, fumariline, fumaritine, fumarophycine, O- } \\
\text { methylfumarophycine, parfumine, } \quad \text { N-methylstylopine }\end{array}$ & 27 \\
\hline Fumaria spicata L. & $\begin{array}{l}\text { Adlumiceine, coptisine, fumariline, fumarophycine, protopine, } \\
\text { N-methylstylopine }\end{array}$ & 27 \\
\hline Fumaria sepium Boiss. & $\begin{array}{c}\text { Dihydrosanguinarine, noroxyhydrastinine, oxyydrastinine, } \\
\text { coptisine, (-)-stylopine, protopine, densiflorine, (-)-fumaritine-N- } \\
\text { oxide, }(+) \text {-parfumine }\end{array}$ & 28 \\
\hline Fumaria indica Hasskn. & Fuyuziphine, $( \pm)$ - $\alpha$-hydrastine & 30 \\
\hline
\end{tabular}

The alkaloids determinated from the previous studies on Fumaria species are shown in table 2. 
Table 2. The alkaloids determinated from Fumaria species

\begin{tabular}{|c|c|c|c|}
\hline SPECIES & $\begin{array}{c}\text { NAME AND QUANTITY OF } \\
\text { ALKALOIDS }\end{array}$ & $\begin{array}{c}\text { METHOD OF } \\
\text { DETERMINATION }\end{array}$ & $\begin{array}{l}\text { NUMBER OF } \\
\text { LITERATURE }\end{array}$ \\
\hline Fumaria gaillardotii Boiss. & $\begin{array}{l}\text { Protopine }(\% 0.11) \text {, fumaritine }(\% \\
0.05) \text {, fumaricine }(\% 0.09), 1 \text {-stylopine } \\
(\% 0.09) \text {, dl-bicuculline }(\% 0.09), \\
\text { N-methylhydrastine }(\% 0.11)\end{array}$ & HPLC & 15 \\
\hline Fumaria judaica Boiss. & $\begin{array}{c}\text { Protopine }(\% 0.18), \mathrm{d} \text {-adlumidine } \\
(\% 0.17), \beta \text {-allocyrtopine }(\% 0.11), \\
\text { 1-stylopine }(\% 0.11) \text {, fumaritine }(\% \\
0.17) \text {, coptisine }(\% 0.04), \text { l-scoulerine } \\
(\% 0.03)\end{array}$ & HPLC & 16 \\
\hline Fumaria macrocarpa Parl. & $\begin{array}{c}\text { Protopine }(\% 0.16), \text { crytopine }(\% \\
0.11), \text { fumariline }(\% 0.11), 1 \text {-sinactine } \\
(\% 0.13), \alpha \text {-adlumine }(\% 0.13), \\
\text { coptisine }(\% 0.07)\end{array}$ & HPLC & 17 \\
\hline Fumaria capreolata L. & $\begin{array}{c}\text { Protopine }(\% 0.11) \text {, cryptopine }(\% \\
\text { 0.09), } \beta \text {-allocryptopine }(\% 0.09), \\
\text { fumaritine }(\% 0.10), 1 \text {-stylopine }(\% \\
0.09) \text {, coptisine }(\% 0.05), 1- \\
\text { capnoidine }(\% 0.12), \text { sanguinarine }(\% \\
0.05)\end{array}$ & HPLC & 18 \\
\hline Fumaria officinalis L. & $\begin{array}{l}\text { Sanguinarine }(\% 0.05) \text {, protopine }(\% \\
0.17) \text {, cryptopine }(\% 0.31) \text {, fumariline } \\
(\% 0.14), \text { d-corydaline }(\% 0.09), \\
\text { 1-sinactine }(\% 0.05) \text {, dl-bicuculline }(\% \\
0.10), \text { fumarofine }(\% 0.19), 1- \\
\text { scoulerine }(\% 0.10)\end{array}$ & HPLC & 19 \\
\hline Fumaria cilicica Hausskn. & $\begin{array}{c}\text { Sanguinarine }(\% 0.09), \text { protopine }(\% \\
0.19), \text { cryptopine }(\% 0.11), \mathrm{d}- \\
\text { corydaline }(\% 0.18), 1 \text {-sinactine }(\% \\
\text { 0.09), dl-bicuculline }(\% 0.15) \\
\text { 1-scoulerine }(\% 0.06)\end{array}$ & HPLC & 19 \\
\hline Fumaria asepala Boiss. & $\begin{array}{l}\text { Protopine }(\% 0.16) \text {, cryptopine } \\
(\% 0.08) \text {, l-stylopine }(\% 0.15), \\
\text { l-scoulerine }(\% 0.05) \text {, d-bicuculline } \\
(\% 0.12) \text {, sanguinarine }(\% 0.04)\end{array}$ & HPLC & 22 \\
\hline Fumaria capreolata L. & $\begin{array}{c}\text { Protopine }(\% 0.12-0.11) \text {, fumarofine } \\
(\% 0.10-0.09), \text { cryptopine }(\% 0.09- \\
0.09)\end{array}$ & $\begin{array}{c}\text { d.p.p. } \\
\text { (differential pulse } \\
\text { polarography)-HPLC }\end{array}$ & 23 \\
\hline Fumaria asepela Boiss. & $\begin{array}{c}\text { Protopine }(\% 0.18-0.17) \text {, cryptopine } \\
(\% 0.13-0.12)\end{array}$ & d.p.p. - HPLC & 23 \\
\hline Fumaria gaillardotii Boiss. & Protopine $(\% 0.12-0.11)$ & d.p.p. - HPLC & 23 \\
\hline Fumaria kraliki Jordan. & $\begin{array}{c}\text { Protopine }(\% 0.40-0.38) \text {, parfumine } \\
(\% 0.13-0.12) \text {, cryptopine }(\% 0.14- \\
0.11) \\
\end{array}$ & d.d.p.-HPLC & 23 \\
\hline Fumaria macrocarpa Parl. & $\begin{array}{c}\text { Protopine }(\% 0.18-0.16) \text {, fumariline } \\
(\% 0.12-0.11) \text {, cryptopine }(\% 0.11- \\
0.11)\end{array}$ & d.d.p. - HPLC & 23 \\
\hline Fumaria judaica Boiss. & $\begin{array}{c}\text { Protopine }(\% 0.19-0.18), \beta- \\
\text { allocryptopine }(\% 0.13-0.11)\end{array}$ & d.d.p. - HPLC & 23 \\
\hline Fumaria vaillantii Loisl. & $\begin{array}{c}\text { Protopine }(\% 0.30-0.27), \mathrm{n}- \\
\text { methylhydrastine }(\% 0.17-0.15), \\
\text { parfumine }(\% 0.19-0.16)\end{array}$ & d.d.p. - HPLC & 23 \\
\hline Fumaria microcarpa Boiss. & $\begin{array}{c}\text { Protopine }(\% 0.33-0.31), \\
\text { n-methylhydrastine }(\% 0.25-0.23), \beta- \\
\text { allocryptopine }(\% 0.37-0.36)\end{array}$ & d.d.p. - HPLC & 23 \\
\hline
\end{tabular}




\begin{tabular}{|c|c|c|c|}
\hline Fumaria parviflora Lam. & $\begin{array}{c}\text { Protopine }(\% 0.45-0.41), \mathrm{n}- \\
\text { methylhydrastine }(\% 0.10-0.09), \\
\text { parfumine }(\% 0.06-0.07) \\
\end{array}$ & d.d.p. - HPLC & 23 \\
\hline Fumaria cilicica Boiss. & $\begin{array}{c}\text { Protopine }(\% 0.21-0.19), \beta- \\
\text { allocryptopine }(\% 0.30-0.30), \\
\text { cryptopine }(\% 0.12-0.11)\end{array}$ & d.d.p. - HPLC & 23 \\
\hline $\begin{array}{c}\text { Fumaria petteri subsp. } \\
\text { thuretii }\end{array}$ & $\begin{array}{c}\text { Protopine }(\% 0.47-0.43) \text {, fumariline } \\
(\% 0.25-0.22) \\
\end{array}$ & d.d.p. - HPLC & 23 \\
\hline Fumaria officinalis L. & $\begin{array}{l}\text { Protopine }(\% 0.19-0.17) \text {, fumariline } \\
(\% 0.15-0.14), \beta \text {-allocryptopine }(\% \\
0.20-0.19) \text {, cryptopine }(\% 0.33-0.31)\end{array}$ & d.d.p. - HPLC & 23 \\
\hline Fumaria densiflora DC. & $\begin{array}{c}\text { Protopine }(\% 0.29-0.27) \text {, fumariline } \\
(\% 0.21-0.20), \beta \text {-allocrptopine }(\% \\
0.32-0.30) \\
\end{array}$ & d.p.p-HPLC & 23 \\
\hline Fumaria parviflora Lam. & $\begin{array}{c}\text { Protopine }(\% 0.42), \text { parfumine }(\% \\
0.07), \text { d-bicuculline }(\% 0.06), \\
\text { hydrastine }(\% 0.16), \\
\text { N-methylhydrastine }(\% 0.09), \mathrm{N}- \\
\text { methylhydrasteine }(\% 0.05), \\
\text { microcarpine }(\% 0.03), \text { sanguinarine } \\
(\% 0.10)\end{array}$ & HPLC & 24 \\
\hline $\begin{array}{l}\text { Fumaria petteri Reichb. } \\
\text { subsp. thuretii Boiss. }\end{array}$ & $\begin{array}{c}\text { Protopine }(\% 0.43), \text { fumariline } \\
(\% 0.22), \text { fumaritine }(\% 0.08), \\
\text { fumaricine }(\% 0.21), \\
\text { l-sinactine }(\% 0.21), \\
\text { scoulerine }(\% 0.11) \text {, coptisine }(\% 0.08) \\
\text {, l-capnoidine }(\% 0.12)\end{array}$ & HPLC & 24 \\
\hline Fumaria kralikii Jordan & $\begin{array}{l}\text { Protopine }(\% 0.38) \text {, cryptopine } \\
(\% 0.11), \text { parfumine }(\% 0.12), \\
\text { 1-scoulerine } 0.08) \text {, d-bicuculline }(\% \\
\text { 0.35), d-adlumine }(\% 0.27), \mathrm{N}- \\
\text { methylhydrasteine }(\% 0.11), \\
\text { sanguinarine }(\% 0.08)\end{array}$ & HPLC & 24 \\
\hline
\end{tabular}

There are some studies on the activity of some Fumaria species which are growing in Turkey:

Abbasoğlu et al. were isolated many isoquinoline alkaloids from Fumaria species growing in Turkey and screened antimicrobial activity of these alkaloids (31).

Şener et al. were screened antibacterial, antifungal, antiinflammatory, analgesic, anti-platelet and antihypertensive activities of the extracts from Fumaria vaillantii. Bioassay directed fractionation using different pharmacological tests with the extracts from Fumaria vaillantii has led to the determination of different bioactive compounds (32).

Aktay et al. were studied the hepatoprotective effects of the extracts of Fumaria asepalea and Fumaria vailantii. They were studied hepatoprotective effects of this plants' ethanolic extracts in rats. The exract of Fumaria vailantii prevented the elevation of plasma and hepatic malondialdehyde formation in active liver injury (33). 
Şener and Orhan were measured acetylcholinesterase inhibitory activity of 10 Fumaria species (Fumaria asepala, F. capreolata, F. cilicica, F. densiflora, F. judaica, F. kralikii, F. macrocarpa, $F$. parviflora, $F$. petteri subsp. thuretii and $F$. vailantii) by a modified spectrophotometric method developed by Ellman. All of the extracts displayed high inhibitory activity (34).

Orhan et al. were studied antiviral and antimicrobial profiles of isoquinoline alkaloids from Fumaria species growing in Turkey. The chloroform:methanol (1:1) extracts of a number of the plant species belonging to Fumaria vaillantii Loiss., F. capreolata L., $\quad$ F. kralikii Jordan., F. asepela Boiss., F. densiflora DC., F. flabellata L., F. petteri Reichb. subsp. thuretii (Boiss.) Pugsley, F. macrocarpa Boiss., F. cilicica Hauskkn., F. parviflora Lam., F. judaica Boiss. were screened for their anticholinesterase activity on acetylcholinesterase and butyrylcholinesterase enzymes by in vitro Ellman method. All of the Fumaria extracts displayed highly potent inhibition against both of the enzymes at $1 \mathrm{mg} / \mathrm{ml}$ concentration compared to the standart (35).

Various techniques ranging from straightforward TLC to complex immunoassays have been used for the determination of isoquinoline alkaloids in plants extracts; however, only a limited number of alkaloids determined with these methods (26).

In this study, TLC-densitometric and spectrophotometric methods have been used to determine the protopine content of Fumaria densiflora DC. The results obtained from the two analytical methods have been compared.

\section{MATERIALS AND METHODS}

\section{Plant Material}

The F. densiflora DC. was collected from West Anatolia in İzmir-Kemalpaşa, in April 1999, and identified by M.Ali Önür. A voucher specimen (No:1239) is deposited in the herbarium of the Department Pharmacognosy of the Faculty of Pharmacy in Ege University, in Izmir.

\section{Extraction of alkaloid}

Aerial parts of plants $(25 \mathrm{~g})$ were dried, powdered and extracted with ethanol in a Soxhlet apparatus until Mayer's test was negative, and then the evaporated in vacuo. The ethanolic residue was taken up in $\% 1$ hydrochloric acid $(50 \mathrm{ml})$, filtered and the aqueous acid solution brought to $\mathrm{pH}$ 9-9.5 with \% 25 ammonium hydroxide and extracted with chloroform $(5 \times 150 \mathrm{ml})$. The extracts were dried over anhidr sodium sulphate and the solvent evaporated to afford a crude extract of alkaloids. 


\section{Reagents and solvents}

Protopine (Merck 7989) was used as a standart. All of the analytical solvents and reagents were purchased from Merck.

\section{Sample solutions}

Sample solutions were prepared by dissolving in chloroform : methanol (8:2) $40 \mathrm{mg}$ (TLC densitometric assay and spectrophotometric assay) of accurately weighed extract in a $10 \mathrm{ml}$ volumetric flask.

\section{TLC-densitometric assay}

A Shimadzu high speed TLC-Scanner CS-920 was used with the following settings: beam size $0.4 \times 0.4 \mathrm{~mm}, \mathrm{X}=24, \mathrm{Y}=10, \mathrm{~L}=3$; AZS off, wavelenght $290 \mathrm{~nm}$. Silica gel $60 \mathrm{~F}_{254}(20 \times 20 \mathrm{~cm}$, $0.25 \mathrm{~mm}$, Merck 5715) plates were used. The mobile phases were $1^{\circ}$ toluene : chloroform : methanol : \%25 ammonium hydroxide $(5: 3: 1: 1)$ and $2^{\circ}$ cyclohexane : diethylamine $(9: 1)$. Samples were applied with Hamilton syringes ( $15 \mathrm{~mm}$ from the bottom edge of the plate). The mobile phase $1^{\circ}$ was allowed to run a distance of $15 \mathrm{~cm}$, mobile phase $2^{\circ}$ was allowed to run a distance of first $10 \mathrm{~cm}$ and second $15 \mathrm{~cm}$ in a satured tank. Protopine solutions $(2,4,6$ and $8 \mu \mathrm{l})$ were applied on a TLC plate and developed under the above mentioned conditions. The developed plates were initially air-dried. The resolved compounds were quantitated on the high-speed TLC scanner at 290 nm using a $\mathrm{D}_{2}$ lamp. The calibration curves (Figure 2 and 3) showed a linear relationship between the concentrations and areas on TLC plates. Aliquots $(20,25$ and $30 \mu \mathrm{l})$ of sample solutions were spotted on each TLC plate, and after the development, the areas of the spot on the plate were integrated by TLC densitometry. For every sample the procedure was repeated three times.

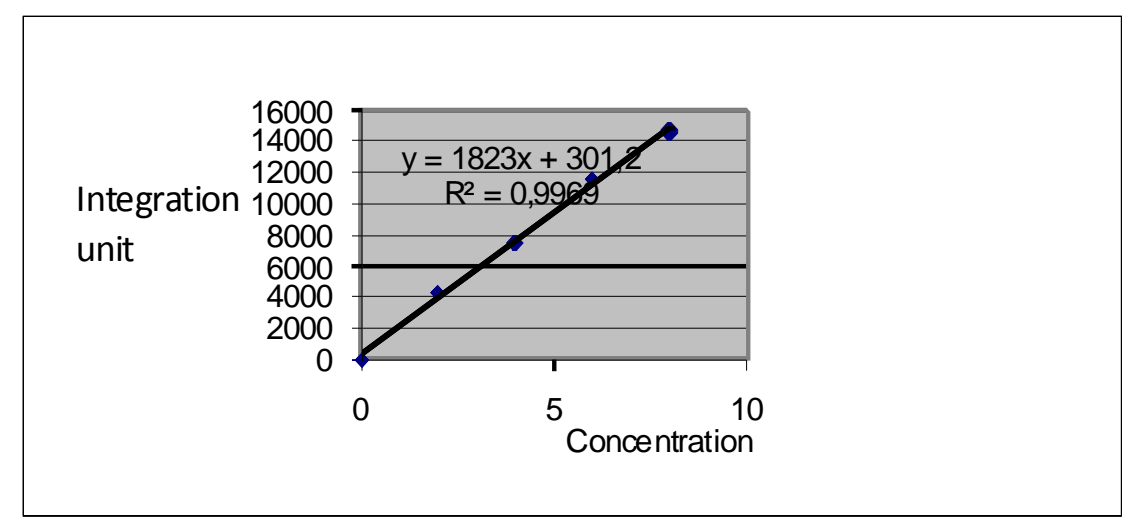

Figure 2. Calibration curve for the determination of protopine by TLC-densitometry in toluene : chloroform : methanol :\%25 ammonium hydroxide $(5: 3: 1: 1)$ 


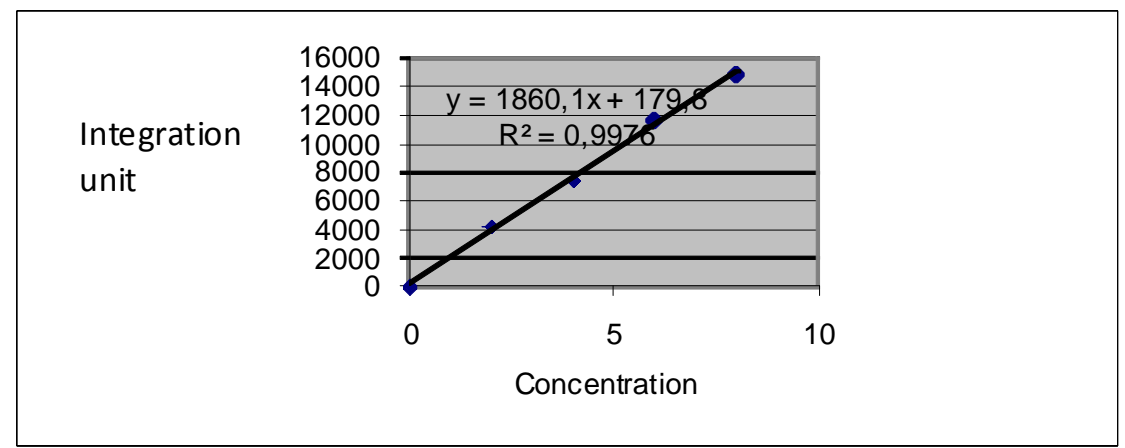

Figure 3. Calibration curve for the determination of protopine by TLC-densitometry in cyclohexane : diethylamine $(9: 1)$

\section{Spectrophotometric Assay}

A Shimadzu UV-160A model spectrophotometer was used. Silica gel G $(20$ x $20 \mathrm{~cm}, 0.5$ $\mathrm{mm}$ thick, Merck 5715) plates were used. The mobile phase was cyclohexane : diethylamine $(9: 1)$. Samples $(40,60,80,100,120,200 \mu \mathrm{l})$ were applied as bands $(10 \mathrm{~cm}$ long $)$ on silica gel $\mathrm{G}$ plates.

After development, the band of protopine was detected under $254 \mathrm{~nm}$ UV-light and scraped. The compound was eluted with chloroform : methanol $(8: 2)$ and the solution was evaporated to dryness. The residue was then dissolved in methanol, transferred to a volumetric flask and the volume was adjusted to $10 \mathrm{ml}$ with methanol. The absorbance of this solution was measured at 290 $\mathrm{nm}$ against a blank using quartz. Then, the standard curve was drawn (Figure 4).

$\mathrm{R}^{2}=0.999$

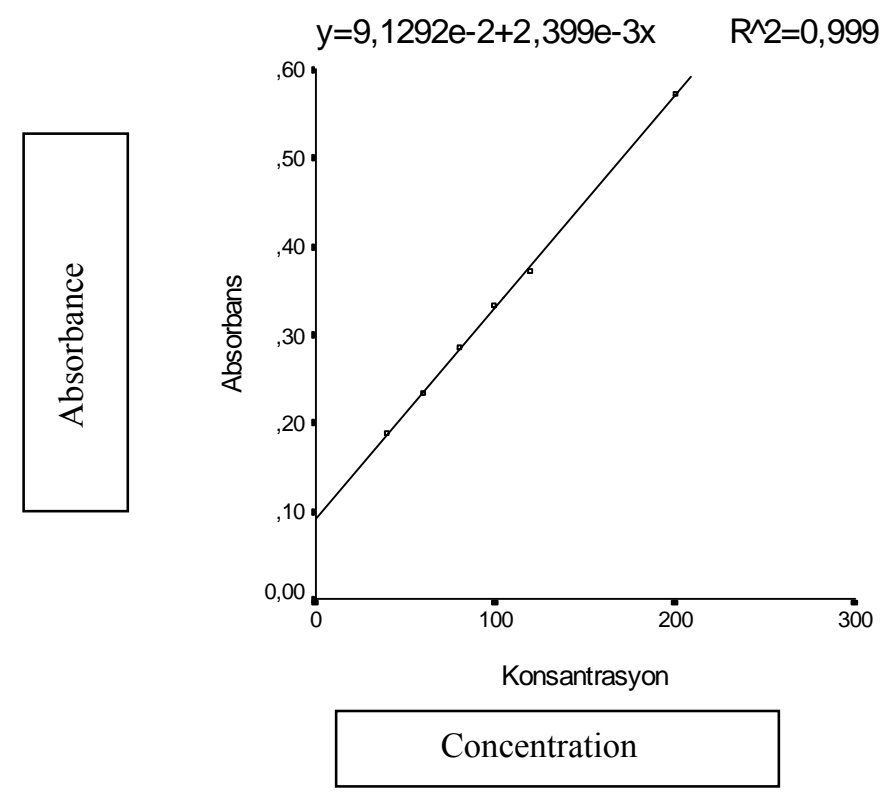

Figure 4. Calibration curve for the spectrophotometric determination of protopine 
The above described procedure was followed by using $40 \mathrm{mg}$ samples. The assay was repeated three times. The protopine content in extracts was calculated from the regression equation of the Standard curve.

\section{Statistical analysis}

Results obtained from the TLC-densitometric and spectrophotometric analyses were as mean \pm S.E. and compared by paired $t$. Test $(\mathrm{p}<0.05)$

\section{RESULTS AND DISCUSSION}

Protopine in Herba Fumariae densiflorae extracts was quantitatively determined by TLCdensitometry and spectrophotometry.

For testing the quantitative accuracy of the TLC-densitometric method, the analyses of the reference subtance and extracts were repeated on three different plates on 2 different solvents. The TLC-densitometric calibration curves (Figure 2 and Figure 3), used to calculate the protopine content in the extracts, was expressed by the following linear equations:

1- According to solvent system [Toluene : chloroform : methanol : \%25 ammonium hydroxide (5:3:1:1)]:

$$
y=1823 x+301.2 ; \mathrm{R}^{2}=0.9969
$$

2- According to solvent system [Cyclohexane : diethylamine (9:1)]:

$$
y=1860.1 x+179.8 ; \mathrm{R}^{2}=0.9976
$$

Where $y$ is the integration unit and $x$ is the protopine concentration $(\mu 1 / \mathrm{ml})$.

For the spectrophotometric assay of protopine, a calibration curve was prepared (Figure 4), expressed by the following linear equation:

$y=9.1292 \mathrm{e}^{-2}+2.3099 \mathrm{e}^{-3 x} ; R^{2}=0.999$

The results of quantitative determinations of protopine in Herba Fumariae densiflorae by TLC-densitometry (in two different solvent system) and spectrophotometry are shown in Table 3. Comparison of the TLC-densitometric results with those obtained from spectrophotometric experiments showed no significant differences, confirming the reliability of the spectrophotometric data. 
Table 3. The results of determination of \% Protopine with TLC-densitometric and spectrophotometric method

\begin{tabular}{|c|c|c|}
\hline Determination method & Solvent system & \% Protopine \\
\hline TLC-densitometry & Cyclohexane:diethylamine $(9: 1)$ & $0.03511 \pm 0.0012$ \\
\hline TLC-densitometry & $\begin{array}{l}\text { Toluene:chloroform:methanol: } \% 25 \\
\text { ammonium hydroxide }(5: 3: 1: 1)\end{array}$ & $0.03521 \pm 0.0007$ \\
\hline Spectrophotometry & Cyclohexane:diethylamine (9:1) & $0.3660 \pm 0.0016$ \\
\hline
\end{tabular}

Temizer et al. determined protopine from some Fumaria species and they found the content of protopine in Fumaria densiflora DC. as 0.29 and $0.27 \%$ by differential pulse polograph and HPLC respectively (23). Suau R. et al. reported the content of protopine in Fumaria densiflora DC. as $0.76 \%$ by GC-MS analysis (29). Our results obtained by the two different methods were similar to Temizer' s study.

\section{ACKNOWLEDGEMENTS}

This research was supported by Ege Üniversitesi Research Fund (No. 01/ECZ/015), İzmir, Turkey.

\section{REFERENCES}

1. Martindale, W., Martindale: The Extra Pharmacopoeia, 31st edn., Pharmaceutical Press, London, p. 2739 (1996)

2. Stübing, G., Peris, J.B., Plantes Medicinales de la Comunidad Valenciana, Generalitat, Valenciana:Valencia, p.297 (1998)

3. Hentschel, C., Dressler, S., Hahn, E.G., "Fumaria officinalis (Fumitory)-Clinical aplications" Fortschritte der Medizin, 113, 291(1995)

4. Giliani, H.A., Samra, B., Janbaz, K.H., Khan, A., "Pharmacological basis for the use of Fumaria indica in constipation and diarrhea”, J. Ethnopharmacol., 96, 585 (2005)

5. Davis, P.H., Flora of Turkey and the East Aegean Islands, Vol.1, Univesity Press, Edinburgh, p. $242(1965)$ 
6. Davis, P.H., Flora of Turkey and the East Aegean Islands, Vol.11, Univesity Press, Edinburgh, p. $28-29(2000)$

7. Forgarcs, P., Jehanno, A., Provost, J., Tieberghien, R., Touche, A., "Alcaloides des Papavéracées: Composition chimique de dix-sept espécesde Fumaria" Plantes médicinales et phytothhérapie tome, $\mathbf{X X}, 1$, p. 64 (1986)

8. Ko-Fn, Wu-Ts, Lu-St, Wu-Yc, Huang-Tf, Teng CM., "Ca ${ }^{+2}$-channel blockade in rat thoracic aorta by protopine isolated from Corydalis tubers" Jap. J. Pharmacol., 58, 1-9 (1992)

9. Teng, CM, Ko-Fn, Wang JP, Liu, CN, Wu-Ts, Chaem, CC, Houng, TF., "Anti haemostatic and anti-thrombosis effect of some anti platelet agents isolated from Chinese herbs." J. Pharm. Pharmacol., 43, 667-669 (1991)

10. Üstünes, L., Laekeman, G.M., Gözler, B., "In vitro study of the anticholinergic and antihistaminic activities of protopine and some derivatives" J. Nat. Prod., 51, 1021-1022 (1981)

11. Casar, A.U., Bilgehan, H., Gözler, T., "The antibacterial effects of some alkaloids isolated from Glaucim flavum crantz." Mikrobiyol Bull., 15, 105-109 (1981)

12. Susplugas, J., El Nouri, S., Massa, V., Susplugas, P., "Spectrophotometrie par remission et fluoromertrie directe des chromatogrammes de la sanguinarine du Fumaria capreolata L.", Trav. Soc. Pharm. Montpellier, 34 (2), 115-120 (1974)

13. Boreisho, N.V., Oleshko, G.I., Molokhova, L.G., "Extraction-photometric determination of protopine by thin-layer chromatography", Rastit. Resur., 13 (3), 534-535 (1977)

14. Şener, B., Gözler, B., Minard, R.D., Shamma, M., “Alkaloids of Fumaria vaillantii”, Phytochemistry, 22 (9), 2073-2075 (1983)

15. Şener, B., "Turkish species of Fumaria L. and their alkaloids II. Alkaloids of Fumaria gaillardotii Boiss.”, Int. J. Crude Drug Res., 21 (3), 135-139 (1983)

16. Şener, B., "Turkish species of Fumaria L. and their alkaloids III. Alkaloids of Fumaria judaica Boiss.”, Int. J. Crude Drug Res., 22 (4), 181-183 (1984)

17. Şener, B., "Turkish species of Fumaria L. and their alkaloids IV. Alkaloids of Fumaria macrocarpa Parlatore.”, Int. J. Crude Drug Res., 22 (4), 185-187 (1984)

18. Şener, B., "Turkish species of Fumaria L. and their alkaloids VI. Alkaloids of Fumaria capreolata L.”, Int. J. Crude Drug Res., 23 (4), 161-163 (1985) 
19. Şener, B., "Turkish species of Fumaria L. and their alkaloids VII. Alkaloids of Fumaria officinalis L. and F. cilicica Hausskn.”, J. Fac. Pharm. Gazi, 2 (1), 45-49 (1985)

20. Aboudi, A.F., Al-Eisawi, D.M., Sabri, S.S., Zarga, M.H.A., "Alkaloids of Fumaria densiflora", J. Nat. Prod., 49 (2), 370 (1986)

21. Forgacs, P., Provost, J., Touche, A., Jehanno, A., "Alkaloids from Fumaria capreolata and Fumaria bella", J. Nat. Prod., 49 (2), 178-179 (1986)

22. Şener, B., "Turkish species of Fumaria L. and their alkaloids VIII. Alkaloids of Fumaria asepela Boiss.”, Int. J. Crude Drug Res., 24 (2), 105-106 (1986)

23. Temizer; A., Kır, S., Şener, B., Orbey, M.T., "Determination of alkaloids by differential pulse polarography II. Fumaria L. alkaloids", J. Pharm. Belg., 42 (6), 382-388 (1987)

24. Şener, B., "Turkish species of Fumaria L. and their alkaloids IX. Alkaloids of Fumaria parviflora L., F. petteri Reichb. subsp. thuretii (Boiss.) Pugsley and F. kralikii Jordan”, Int. J. Crude Drug Res., 21 (3), 135-139 (1983)

25. Taborska, E., Bochorakova, H., Sousek, J., Sedmera, P., Vavreckova, C., Simanek, V., "Fumaria densiflora DC. alkaloids", Collect. Czech. Chem. Comm., 61 (7), 1064-1072 (1996)

26. Souśek, J., Adam, T., Bochoŕáková, H., Táborská, E., Śimánek, V., "HPLC and GC-MS analysis of alkaloids and acids in the species of the genus Fumaria", Ceska Slov. Farm., 47 (1), 36-39 (1998)

27. Souśek, J., Guédon, D., Adam, T., Bochoŕáková, H., Táborská, E., Valka, I., Śimánek, V., “Alkaloids and organic acids content eight Fumaria species", Phytochem. Anal., 10 (1), 6-11 (1999)

28. Suau, R., Cabezudo, B., Rico, R., Lopez-Romero, J.M., Nájera, F., "Alkaloids from Fumaria sepium and Fumaria agraria", Biochem. Systemat. Ecol., 30, 263-265 (2002)

29. Suau, R., Cabezudo, B., Rico, R., Lopez-Romero, J.M., Nájera, F., "Direct determination of alkaloid contents in Fumaria species by GC-MS", Phytochem. Anal., 13, 363-367 (2002)

30. Pandey, M.B., Singh, A.K., Singh, J.P., Singh, V.P., Pandey, V.B., "Fuyuziphine, a new alkaloid from Fumaria indica", Nat. Prod. Res., 22 (6), 533-536 (2008)

31. Abbasoğlu, U., Şener, B., Günay, Y., Temizer, H., "Antimicrobial activity of some isoquinoline alkaloids", Arch. Pharmazie, 324 (6), 379-380 (1991) 
32. Şener, B., "Recent results in the search for bioactive compounds from Turkish medicinalplants", Pure Appl. Chem ., 66 (10-11), 2295-2298 (1994)

33. Aktay, G., Deliorman, D., Ergun, E., Ergun, F., Yeşilada, E., Çevik, C., "Hepatoprotective effects of Turkish folk remedies on experimental liver injury", J. Ethnopharmacol., 73, 121$129(2000)$

34. Şener, B., Orhan, I., "Molecular diversity in the bioactive compounds from Turkish plants evaluation of acetylcholinesterase inhibitory activity of Fumaria species", J. Chem. Soc. Pakistan, 26 (3), 313-315 (2004)

35. Orhan, I., Özçelik, B., Karaoğlu, T., Şener, B., "Antiviral and antimicrobial profiles of selected isoquinoline alkaloids for Fumaria and Corydalis species", Zeitschrift fur naturforschung C-J. Biosci., 62 (1-2), 19-26 (2007)

Received: 23.06.2008

Accepted: 18.09 .2008 
